\title{
Sensitivities of two tropical epibenthic amphipodsto physical chemical variables and reference toxicants
}

\author{
Passarelli, M.C. ${ }^{1}$; Abessa, D.M.S. ${ }^{2}$ \& Cesar, A. ${ }^{1 ; 3}$ \\ ${ }^{1}$ UNISANTA, Universidade Santa Cecília, Departamento de Ecotoxicologia, Santos, Brazil. \\ ${ }^{2}$ UNESP, Universidade Estadual de São Paulo, Campus Experimental do litoral Paulista, São Vicente, SP, Brazil. \\ ${ }^{3}$ UNIFESP, Universidade Federal de São Paulo, Departamento de Ciências do Mar, Santos, SP, Brazil.
}

Received March 07, 2019; Accept June 14, 2019

\begin{abstract}
This study sought to evaluate the sensitivity of two epibenthic amphipods (Hyalenigraand Hyaleyoungi) to reference substances inorder toevaluate their potential as test-organisms in ecotoxicological studies. First, theoptimal ranges of salinity, temperature, and $\mathrm{pH}$ were estimated for both species. Then, toxicity tests with different reference toxicants were conducted. The selected contaminants were cadmium chloride $\left(\mathrm{CdCl}_{2}\right)$, sodium dodecyl sulfate detergent $\left(\mathrm{C}_{12} \mathrm{H}_{25} \mathrm{NaO}_{4} \mathrm{~S}\right)$, ammonium chloride $\left(\mathrm{NH}_{4} \mathrm{Cl}_{2}\right)$, potassium dichromate $\left(\mathrm{K}_{2} \mathrm{Cr}_{2} \mathrm{O}_{7}\right)$, and zinc sulfate $\left(\mathrm{ZnSO}_{4}\right)$.The mortalities were recorded and the effectiveconcentrations to $50 \%$ organisms (LC50 ${ }_{96 \mathrm{~h}}$ )were estimated. Sensitivities of both species were similar to those reported in studies on other amphipods, which is evidence of the potential of these species to serve as test organisms in ecotoxicological studies.
\end{abstract}

Keywords: Reference substances, Hyalenigra; Hyaleyoungi; Toxicity tests.

\section{INTRODUCTION}

Over the last few decades, aquatic ecosystems have been degraded due to human activities. Pollution is considered the main threat to aquatic environments, and it demands attention from stakeholders and actions from the government. Environmental agencies have focused on the development and employment of environmental monitoring techniques, among which chemical and ecotoxicological approaches stand out (Environmental Canada 1992; USEPA 1996; 2002). Environmental analyses have placed emphasis on sediment quality assessment (Bohrer 1995),since this area of environmental restudies consists of one substrate for many organisms; however, sediments can accumulate chemical substances in concentrations much higher than those found in the water column (Adams et al. 1985; Petrovic and Barceló 2004).Moreover, contaminated sediments represent a secondary source of pollutants for the benthic and epibenthic biota and the water column, and they are capable of negatively impacting the quality of waters and biota even when the primary source of pollution has ceased (Araújo et al. 2006).

When one also considers the increasing number of potentially toxic substances that are released into marine and coastal environments, the development of new methods to properly evaluate the risks and effects in different environments and organisms is more clearly understood as an urgent need that has not been met. In this case, toxicity tests are cost-effective tools that may provide direct, quantifiable evidence of the biological consequences of contamination, and can be used to measure the interactive toxic effects of complex contaminant mixtures in water and sediment (Cesar et al. 2002).

Toxicity testing has been widely used to assess the quality of sediments around the world, and most studies have employed amphipods as test-organisms (Nipper et al.1989; Cesar et al. 2002; Molisaniet al. 2013; Basalloteet al. 2014), since they are highly responsiveto many kinds of contaminants, and have been used to evaluate the quality of whole sediments (Environment Canada 1992; ASTM 2014;

*Corresponding author: Marina Passarelli; e-mail: marinapassarelli@gmail.com 
Podlesinska\&Dabrowska 2019). However, in the tropical and subtropical regions of the Southwest Atlantic, there are only two nativeamphipod species (Tiburonellaviscana and Grandidierellabonnieroides) with standardized protocols for their use in toxicity tests (ABNT NBR 15638/2008; Abessa et al. 1998; Melo 1993; Melo \&Abessa 2002; Molisaniet al. 2013). Considering the diversity of coastal and marine environments from the Southwest Atlantic, this number is clearly insufficient, thus, there is a need to expand the number of possible testspecies and protocolsin order to better represent the marine/estuarine biota in ecotoxicological studies, especially when sediments are considered.

According to the USEPA (1994), potential testorganisms must fulfill some characteristics (for example, they must be sensitive to contaminants but tolerant to laboratory conditions and handling). Additionally, the organism's distribution, biology and physiology, living habits, and level of sensitivity must be known in order to guarantee that the species will produce reliable results on the toxic effects of a substance or an environmental sample.

This study sought to assess the sensitivity of two Brazilian's epibenthic marine amphipods (Hyalenigra and Hyaleyoungi) to reference contaminants in order todetermine their potential as test-organisms in toxicity tests. Passarelli et al. (2016) reported the potential of sensitivity of the Brazilian amphipod Hyalenigrato be used as test organisms in sediment toxicity tests and another study showed the sensitivity of Hyaleyoungito enrichment of $\mathrm{CO}_{2}$ in seawater (Goulding et al. 2017). However, this is the first attempt evaluating the sensitivity of these species to toxic substances in water that is useful as reference assay, and considering the environmental parameters.

The ultimate goal of this study was to provide new ecotoxicological tools for evaluating the quality of tropical and subtropical marine ecosystemsthat include not only whole sediment testing, but also elutriate and sediment-water interface since the $H$. youngi and $H$. nigra species have epibenthic habits and are exposed to the contaminants by different routes.

\section{MATERIALS AND METHODS}

\section{Collection, Selection and Acclimation of Test Organisms}

Individuals ofHyalenigra (Fig. 1a) and Hyaleyoungi (Fig. 1b) were collected from stalks of the macroalgae Ulva spwhich were



obtained from rocky reefs from the beaches of Santos and Guarujá,

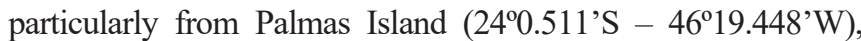
which is located in the Santos Bay, São Paulo, Brazil.

The algae stalks were collectedin the intertidal zone, conditioned in cool boxes with seawater and aeration, and then transported to the laboratory (ABNT NBR 15638/2008). The collected material was then screened, and the organisms were separated by species; juveniles and egg-bearing females were excluded. Species identification was conducted with the aid of specialized bibliography and identificationkeys (Barnard \&Karaman 1991; Serejo 2001). The selected organisms were acclimated to the test conditions in glass tanks with $1 \mathrm{~L}$ of filtered natural seawater. During the acclimatization period, the organisms receiveddaily feedings ofUlva lactuca and $1.5 \mathrm{ml}$ of concentrated fish food $\left(2 \mathrm{~g}\right.$ of TetraMin ${ }^{\circledR}$ fishfoodin $80 \mathrm{ml}$ of pond seawater that were stirred until small flakes formed). Small pieces of nylon-type mesh were used as an artificial substrate; these mesh pieces were added to each test chamber using the procedureestablished by the Brazilian protocol for toxicity testing with the freshwater amphipodHyalellaspp (ABNT NBR 15470/2007). Table 1.shows the conditions and feasibility criteria of the toxicity tests with $H$. nigra and $H$. youngispecimens found during the preliminary tests performed to establish the limiting parameters.

\section{Characterization of Limiting Parameters}

Hyalenigra and $H$. youngi specimens were exposed to different salinities $(5,10,15,20,25,30,35$ and 40) at three temperatures $\left(15^{\circ} \mathrm{C}, 20^{\circ} \mathrm{C}\right.$ and $\left.25^{\circ} \mathrm{C}\right)$. The test solutions were prepared by diluting filtered clean seawater with distilled water or using reconstituted water obtained by the dilution of commercial sea salts $\left(\mathrm{RedSea}^{\circledR}\right)$ in distilled water; 3 replicates were used for each treatment. Then, the test-organisms were transferred to $1 \mathrm{~L}$-polyethylene chambers containing $400 \mathrm{ml}$ of test solutionwith continuous gentle aeration and daily feed. After 10 days, the surviving amphipods in each replicate were counted. Subsequently, and using a similar test procedure, the organisms were exposed to three $\mathrm{pH}$ conditions (7.5; $8.0 ; 8.5)$ for 10 days using the optimal values of salinity and temperature estimated in the previous tests. The seawater used in this step presented an initial $\mathrm{pH}$ of 8.67 , which required

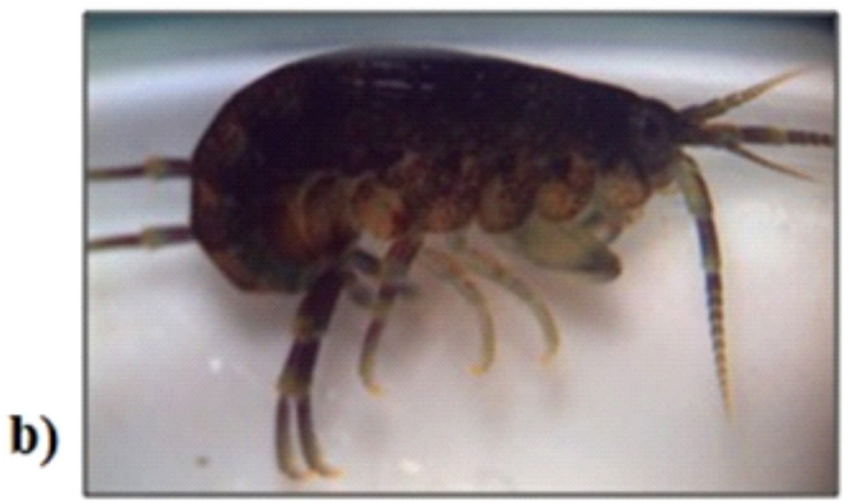

Figure 1. Species employed in the study: 1a. Hyalenigra and 1b. Hyaleyoungi. (scale: 0 to $2 \mathrm{~cm}$ ) 
Table 1 . Summary of conditions and feasibility criteria of the toxicity tests (aqueous fraction) with Hyaleyoungi and Hyalenigra.

\begin{tabular}{lc}
\hline Parameters & Terms \\
\hline Type of essay & Static \\
Exposure period & 96 hours \\
Temperature & $20^{\circ} \mathrm{C}-25^{\circ} \mathrm{C}$ \\
Salinity & $35 \pm 2(30-40)$ \\
$\mathrm{pH}$ & $7.5-8.5$ \\
Photoperiod & Continuous light \\
Test chamber & $1 \mathrm{~L}$ poly-ethylene chambers \\
Volume of test solution & 400 ml \\
Number of organisms per & 10 organisms \\
replication & $\geq 3$ replicates \\
Number of replicates per & Continuous and gentle \\
treatment & Natural filtered seawater $(0.45$ \\
Aeration & $\mu$ m) \\
Dilution water & Adults (no ovigerous females) \\
Age of organisms tested & Lethality (LC50) \\
Observed effect & Minimum survival in control $=$ \\
Test validity & $85 \%$ \\
\hline
\end{tabular}

adjustments: $10 \% \mathrm{HCl}$ was added the water in order toreduce the $\mathrm{pH}$ to the proposed values used in the experiment.

\section{Sensitivity of Test Organisms}

The sensitivity of $H$. nigra and $H$. youngi was evaluated through toxicity tests, which wereperformed using the following reference toxicants: cadmium (as cadmium chloride - $\mathrm{CdCl}_{2}$ ); sodium dodecyl sulfate detergent (SDS $\mathrm{C}_{12} \mathrm{H}_{25} \mathrm{NaO}_{4} \mathrm{~S}$ ), ammonia (as ammonium chloride - $\mathrm{NH}_{4} \mathrm{Cl}_{2}$ ), chromium (as potassium dichromate $-\mathrm{K}_{2} \mathrm{Cr}_{2} \mathrm{O}_{7}$ ), and zinc (as zinc sulfate - $\mathrm{ZnSO}_{4}$ ). The selected toxicants have been recommended worldwide as reference substances (ASTM 1992; Environment Canada 1995; Schipper et al. 1999; Swartz et al. 1985; USEPA 1994; ABNT NBR 15638/2008).

The definitive concentrations were determined from preliminary tests withdilution factors of 1.5 to 2.0.Dilutions were performed with natural filtered seawater $(0.45 \mu \mathrm{m})$ and chemical agents; all reagents used in the assays were of analytical grade. Five tests were performed with each substance and $H$. nigra; in the tests with $H$. youngi, the number of experiments changed according to the substance: three tests were performed with $\mathrm{CdCl}_{2}$, SDS and $\mathrm{K}_{2} \mathrm{Cr}_{2} \mathrm{O}_{7}$, two tests were conducted with $\mathrm{NH}_{4} \mathrm{Cl}_{2}$, and one test was performed with $\mathrm{ZnSO}_{4}$. Five concentrations plus control seawater were used; the final concentrations were determined from preliminary tests. For all tested substances, 3 replicates were prepared for each concentration. They were prepared in $1 \mathrm{~L}$ polyethylene bottles containing $400 \mathrm{ml}$ of the test solution and ten organisms. Small pieces of nylon mesh were introduced into each replicate as an artificial substrate. All tests lasted $96 \mathrm{~h}$ and were set up in a temperature-controlled room $\left(25 \pm 2^{\circ} \mathrm{C}\right)$ with continuous light. At the beginning and the end of each experiment, the overlying water physical-chemical parameters (temperature, salinity, dissolved oxygen and $\mathrm{pH}$ ) were measured in order to ensure the acceptability of the tests, and measurements followed standard methods (APHA 1998).

\section{Data Analyses}

The results of the characterization parameters were analyzed statistically using TOXSTAT Software, version 3.5. The data were checked for normality using the chisquare method and for homogeneity of variances using Bartlett's test and then their percentage were measured.

As an estimation of the lethal concentrations for the amphipods, the $\mathrm{LC} 0_{96 \mathrm{~h}}$ values and their respective $95 \%$ confidence limits were calculated for all substances using the Trimmed Spearman-Karber method (Hamilton et al. 1977) with Abbott's formula. The precision of the laboratory data was calculated for each species/substance through the calculation of the coefficients of variation (CVs), using the mean (LC50) and relative standard deviation with the following equation:

$$
C V \%=\frac{\text { Standarddeviationof } L C 50}{\text { MeanLC50 }} \times 100
$$

\section{RESULTS}

The results obtained in the experiments combining different salinities and temperaturesare shown in Figure 2. The results showed optimal survival rates of $H$. nigra ata salinity of 35 and at $20^{\circ} \mathrm{C}$, conditions under which $95 \%$ of exposed organisms survived (Fig. 2a). ForH. youngi, the best survival rates were observed at salinity of 35 and at both $20^{\circ} \mathrm{C}$ and $25^{\circ} \mathrm{C}$; under these conditions, survival rates were $\geq 86 \%$ (Fig. 2b).However, the minimum survival rate acceptable by ABNT NBR 15638 is $85 \%$. In this sense, it was also observed great survival at salinity 30 and at $20^{\circ} \mathrm{C}$ and $25^{\circ} \mathrm{C}$, using the H. youngi species and from salinity 30 to 40 and under all temperatures employed for the H. nigra species.

The best results obtained in the tests with different $\mathrm{pH}$ levels occurred at 8.5 in the tests with both species. Survival rates $\geq 80 \%$ were also observed under other conditions, including salinities between 30 and 40 , temperatures between $20^{\circ} \mathrm{C}$ and $25^{\circ} \mathrm{C}$, and $\mathrm{pH}$ levels between 7.5and 8.5 (Table 2).

The results of the tests with reference substances are shown in Table 3. The mean $\mathrm{LC} 50_{96 \mathrm{~h}}$ values in the tests with $\mathrm{NH}_{4} \mathrm{Cl}_{2}$ were $139.73 \pm 18.5 \mathrm{mgL}^{-1}$ for $H$. nigra and $214.54 \pm 23.84 \mathrm{mg} \mathrm{L}^{-1}$ for $H$. youngi. In the tests with SDS, the mean $\mathrm{LC} 50_{96 \mathrm{~h}}$ values were $4.63 \pm 0.59 \mathrm{mgL}^{-1}$ and $16.67 \pm 8.20 \mathrm{mgL}^{-1}$, respectively. In the tests with potassium dichromate, mean LC $50_{96 \mathrm{~b}}$ values were relatively similar, with respective values of $36.37 \pm 8.25 \mathrm{mgL}$ ${ }^{1}$ and $28.83 \pm 2.44 \mathrm{mgL}^{-1}$; both species exhibited similar a mean LC50 ${ }_{96 \mathrm{~b}}$ value in the tests with $\mathrm{CdCl}_{2}\left(0.53 \pm 0.11 \mathrm{mg} \mathrm{L}^{-1}\right.$ and $0.44 \pm$ $\left.0.08 \mathrm{mgL}^{-1}\right)$ and $\mathrm{ZnSO}_{4}\left(0.60 \pm 0.18 \mathrm{mgL}^{-1}\right.$ and $\left.0.37 \mathrm{mgL}^{-1}\right)$ for $H$. nigra and $H$. youngi, respectively. The sensitivity of both species to the reference toxicants tended to vary little among experiments, and CVs lower than 30\% were observed in some substances. Sodium dodecyl sulfate produced the lowest CVamong the studies on H. nigra (17\%), while in the studies onH. youngi, the lowest $\mathrm{CV}$ was observed with potassium dichromate $(10 \%)$. 



Figure 2. Mean values of different salinity and temperature to the amphipods Hyalenigra (2a) and Hyaleyoungi (2b). ( \pm standard deviation)

Table 2.Results of the tests with different $\mathrm{pH}$ levels using the amphipods Hyaleyoungiand Hyalenigra.

\begin{tabular}{ccc}
\hline $\mathrm{pH}$ & $\begin{array}{c}\text { \% Survival } \\
\text { (Hyaleyoungi) }\end{array}$ & $\begin{array}{c}\text { \% Survival } \\
\text { (Hyalenigra) }\end{array}$ \\
\hline 7.5 & $85 \%$ & $83 \%$ \\
8.0 & $85 \%$ & $85 \%$ \\
8.5 & $90 \%$ & $86 \%$ \\
\hline
\end{tabular}

Table 3. Mean LC50 ${ }_{96 \mathrm{~h}}$ values obtained in toxicity tests with Hyalenigra and Hyaleyoungi exposed to reference substances. Concentrations are expressed as $\mathrm{mg} \mathrm{L}^{-1}$. Results are expressed as means and respective standard deviations (SD) and coefficients of variation $(\mathrm{CV})$.

\begin{tabular}{|c|c|c|c|c|}
\hline \multirow{3}{*}{ Substance } & \multicolumn{4}{|c|}{ Species } \\
\hline & \multicolumn{2}{|l|}{ H. nigra } & \multicolumn{2}{|c|}{ H. youngi } \\
\hline & Mean \pm SD & $\mathrm{CV}$ & $\begin{array}{c}\text { Mean } \pm \\
\text { SD }\end{array}$ & $\mathrm{CV}$ \\
\hline $\mathrm{NH}_{4} \mathrm{Cl}_{2}$ & $139.73 \pm 18.5$ & $18 \%$ & $\begin{array}{c}214.54 \\
\pm 23.84\end{array}$ & $14 \%$ \\
\hline $\mathrm{C}_{12} \mathrm{H}_{25} \mathrm{NaO}_{4} \mathrm{~S}$ & $4.63 \pm 0.59$ & $17 \%$ & $\begin{array}{c}16.67 \pm \\
8.20\end{array}$ & $46 \%$ \\
\hline $\mathrm{K}_{2} \mathrm{Cr}_{2} \mathrm{O}_{7}$ & $36.37 \pm 8.25$ & $41 \%$ & $\begin{array}{c}28.83 \pm \\
2.44\end{array}$ & $10 \%$ \\
\hline $\mathrm{CdCl}_{2}$ & $0.53 \pm 0.11$ & $34 \%$ & $\begin{array}{c}0.44 \pm \\
0.08\end{array}$ & $29 \%$ \\
\hline $\mathrm{ZnSO}_{4}$ & $0.60 \pm 0.18$ & $75 \%$ & 0.37 & - \\
\hline
\end{tabular}

When both species were compared, H. nigrawas found to bemore sensitive to $\mathrm{NH}_{4} \mathrm{Cl}_{2}$ and $\mathrm{Cl}_{2} \mathrm{H}_{25} \mathrm{NaO}_{4} \mathrm{~S}$; in the studies using the other substances, sensitivities can be considered comparable.

\section{DISCUSSION}

Amphipods are considered suitable indicators of environmental quality because they are sensitive to different types of contaminants in aquatic environments.
An important aspect that must be known regarding any species' potential to be a biological model in ecotoxicological evaluations is the definition of its tolerance limits to physicalchemical parameters. These parameters may interfere on the interpretation of the data, and they could be considered confounding factors that can sometimes cause false-negative and/ or false-positive results. According toSerejo (2001) H. nigraand H. youngispecimensoccur along the coast of the Brazilian states of Bahia, Rio de Janeiro and São Paulo, and they are generally associated with macroalgae found in rocky shores. Temperature is a factor thatstrongly influences these species, and it must be monitored and controlledduring the conduction of laboratory tests (Kinne 1961; Fish \& Preece 1970; Barnett 1971).

The tolerance rangefor $H$. nigraand H.youngi (highest survival at salinities between 30 and 40and temperatures between $20^{\circ} \mathrm{C}$ and $25^{\circ} \mathrm{C}$ ) were expected as they are typicalof marine habitats in tropical and subtropical areas.Although the $H$. youngi amphipod has showed a lower survival rates at salinity 20 under $25^{\circ} \mathrm{C}$, its application is still recommended and acceptable when the experiments conditions are controlled following the criteria mentioned in the table 1 (optimal conditions for the application of these species). Moreover, a previous study has reported a significant mortality of $H$. youngi species at $\mathrm{pH} \leq 6.5$ (Goulding et al. 2017) while the results obtained in this study showedhigher survival at the highest $\mathrm{pH}$ level tested ( $\mathrm{pH} 8.5$ ) which confirm the sensitivity of this species to acidified conditions ( $\mathrm{CO}_{2}$ enrichment).

Another pre-requisite of a test-species candidate is the sensitivity to a range of contaminants. This can be measured through experiments with reference substances. These experiments are performed with determined toxicants (USEPA 1994; ABNT NBR 15638/2008) which toxicities are known for many species,in order to allow furthercomparisons (Lee 1980). The LC50 ${ }_{96 \mathrm{~h}}$ values found in this study to both species (Hyaleyoungiand $\mathrm{H}$. nigra) were similar to those reported in the literature for other species. Both species present similar habits and aspects with specific difference in their taxonomy. In the case of H.nigra, the taxonomic differentiation is found in pereopods from 5 to 7 with 3 single spines present and in 
the branch of uropods 1 and 2 with marginal spines. On the other hand, H.youngi presents large and striated arrows in the dypsus of pereopods from 3 to 7 , and the peduncle of uropode 1 with lateral spine (Serejo 2001).

Table 4 shows a comparison of the $\mathrm{LC} 50_{96 \mathrm{~h}}$ values obtained in tests with several reference toxicants, including the species used in the current study.Responses to the differentsubstances tended to vary little among experiments, with exception of H.nigra response of to $\mathrm{ZnSO} 4$, for which the $\mathrm{CV}$ was $75 \%$.

The literature recommends CVs of $30 \%$ or lower for control charts produced with at least 20 tests (Environment Canada 1992); however, the higher values observed in this study may have been due to the low number of experiments and also because the the organisms were collected in the field, being subject to environmental fluctuations that could have influenced on their physiology and conditions. Further studies with these species and reference toxicants could provide more reliable data on their sensitivity and the refinement of the sensitivity ranges; they would also subsidize the preparation of control charts, which consist of an important tool to assess the sensitivity of test-organisms.

The mean values of $\mathrm{LC}_{50}$ found for cadmium $\left(\mathrm{CdCl}_{2}\right)$ were $0.32 \mathrm{mg} \mathrm{L}^{-1}$ for H. nigra and $0.27 \mathrm{mg} \mathrm{L}^{-1}$ for H. youngi, similar to those reported for the amphipods Corophiummultisetosum, Corophiuminsidiosum and Gammarus aequicauda that were: $0.31 \mathrm{mg} \mathrm{L}^{-1}, 0.35 \mathrm{mg} \mathrm{L}^{-1}$ and $0.26 \mathrm{mg} \mathrm{L}^{-1}$, respectively (Réet al. 2009; Pratoet al. 2006). However, higher values were found for the amphipods Corophiuminsidiosum $\left(1.68 \mathrm{mg} \mathrm{L}^{-1}\right)$ and Corophiumorientale (3.3 $\mathrm{mg} \mathrm{L}^{-1}$ ) (Piconeet al. 2008; Prato \&Biandolino 2006).

Theresults obtained in the present studyproduced a LC50 of $0.26 \mathrm{mg} \mathrm{L}^{-1}$ and $0.37 \mathrm{mg} \mathrm{L}^{-1}$ of $\mathrm{ZnSO}_{4}$ for $H$. nigraand $H$. youngi, respectively, whichwere relatively close to the value of the $\mathrm{LC}_{50}$ reported in the literature for T. viscana $(0.79 \mathrm{mg}$ $\left.\mathrm{L}^{-1}\right)$ (Melo \& Nipper 2007).

King et al. (2006) evaluate the sensitivity to zincin seven species of amphipods (Chaetocorophiumlucasi,
Corophiumcolo, Grandidirella japonica, Hyalelongicornis, Melita awa, Melita matilda e Melita plumulosa)in adult (10 days) and juvenile (96 hours) phases. Their results showed that the highest sensitivity was exhibited by $H$. longicornisat juvenile stage (LC50 of $0.05 \mathrm{mg} \mathrm{L}^{-1}$ ), and adult individuals (LC50 of $0.19 \mathrm{mg} \mathrm{L}^{-1}$ ). The most tolerant species reported by King et al. (2006) was C. color (LC50 of $0.45 \mathrm{mg} \mathrm{L}^{-1}$ ), and its sensitivity was comparable with those presented in this study by $H$. nigra and $H$. youngi.

In addition, both species ( $H$. nigra and $H$. youngi)of amphipods investigated in this study were relatively tolerant to ammonia. This should be considered advantageous for the evaluation of the toxicity of sediments since ammonia is considered a non-persistent confounding factor ratherthan a contaminant of concern; besides, itconfirm the potential of these species as bioindicators of aquatic environmental health.

On the other hand, it is highlighted that the majority of standardized species have burrowing habits however the use of epibenthic species may be very versatile since these organisms are exposed to the contaminant in the sediment from different ways.Although the species used in this study have epibenthic habitats, individuals of both species ( $H$. nigra and $H$. youngi) were observedburied in the sand near the algae during collection, indicating that this behavior may occur depending on the situation in which the organism is found.

Furthermore, there are other species with distinct habits that are standardized, such as Gamarusaequicauda and Ampeliscaabdita (Cesar et al. 2004; USEPA 1994). Also, the Brazilian standard ABNT NBR 15470/2007 establishes a protocol to sediment toxicity tests with epibenthic species of sweet habits (Hyalellasp), which is basically the same applied in the present study, except for some adaptations regarding the amount of sample used and age of the test organisms.

\section{CONCLUSION}

The present study provides information on the sensitivity of epibenthic marine amphipods Hyalenigraand Hyaleyoungi

Table 4. Comparison of LC50 values obtained from tests with reference substances and different species of marine amphipods .a) LC50 ${ }_{96 \mathrm{~h}}$; b) LC50 ${ }_{48 \mathrm{~h}}$; $\left.\mathrm{c}\right)$ $\mathrm{LC} 0_{72 \mathrm{~h}}$.

\begin{tabular}{lcccccc}
\hline \multirow{2}{*}{ Species } & \multicolumn{5}{c}{ ReferenceToxicant $\left(\mathrm{mg} \mathrm{L}^{-1}\right)$} & \multirow{2}{*}{ Author(s) } \\
\cline { 2 - 6 } & $\mathrm{NH} \mathrm{Cl}$ & $\mathrm{SDS}$ & $\mathrm{CdCl}$ & $\mathrm{K} \mathrm{Cr} \mathrm{O}^{2}$ & ZnSO & \\
\hline Hyalenigra $^{\text {a) }}$ & $103^{4} .42^{2}$ & 3.45 & $0.32^{2}$ & $1^{2} 9.8^{2} 8^{7}$ & $0.26^{4}$ & Thisstudy \\
Hyaleyoungia $^{\text {Tiburonellaviscana }}{ }^{\text {b) }}$ & 166.85 & 8.47 & 0.27 & 23.95 & 0.37 & Thisstudy \\
Tiburonellaviscana $^{\text {b) }}$ & - & 3.41 & - & 9.8 & 0.79 & Melo \&Nipper 2007 \\
Tiburonellaviscana $^{\text {c) }}$ & - & - & - & 11.22 & - & Abessa\& Sousa 2003 \\
Tiburonellaviscana $^{\text {b) }}$ & 28.74 & - & - & - & - & Abessa 2002 \\
Gammarusaequicauda $^{\text {b) }}$ & - & 5.87 & - & 9.8 & - & Abessa 2002 \\
Microdeutopusgryllotalpa $^{\text {b) }}$ & - & 5.56 & 0.26 & 9.52 & - & Cesar et al. 2004 \\
Corophiummultisetosum $^{\text {a) }}$ & - & 2.98 & - & 6.06 & & Cesar et al. 2004 \\
Eohaustoriusestuarius $^{\text {a) }}$ & 125.5 & - & 0.31 & - & - & Ré et al. 2009 \\
Grandidierellajaponica $^{\text {a) }}$ & 148.3 & & - & - & - & Kohn et al. 1994 \\
Corophiuminsidiosumm $^{\text {a) }}$ & - & - & 0.35 & - & - & Prato et al. 2006 \\
Crorophiumorientale $^{\text {a) }}$ & - & - & 3.3 & - & - & Piconeet al. 2008 \\
\hline
\end{tabular}


to physical-chemical water variables and reference substances. The results showed that these species present typical marine and tropical habits with excellent survival between salinities at $30-40,20{ }^{\circ} \mathrm{C}-25^{\circ} \mathrm{C}$ of temperature and $\mathrm{pH}$ levels of 8.5. In the tests with the toxic reference substances, the results indicated that the amphipods used in this study are sensitive to the different compoundstested, and were similarly responsive compared toother invertebrate species used in toxicity testing. The amphipod $H$. nigra showed higher sensitivity than $H$. youngi, with exception ofcadmium chloride, which was more toxic to the latter.

Therefore, the results obtained in this study showed the good sensitivity of the species Hyalenigra and Hyaleyoungi to all the reference substances tested, and consequently, prove their potential of application in toxicity tests providing new options of species to be to evaluate quality of sediment when demanded by the Brazilian legislation. Further studies on the biology of these species and their sensitivity to other environmental parameters (such as sediment textures and organic enrichment) and environmental samples should be conducted, in order to confirm the results of this study and the usefulness of both species in toxicity testing with sediments.

\section{ACKNOWLEDGEMENTS}

This study was funded by the São Paulo Research Foundation - FAPESP (grant \#2011/159248). A. Cesar and D. Abessa thank theCNPq (Conselho Nacional de Desenvolvimento Científico e Tecnológico, MEC - Brazil) for their respective research productivity fellowships (PQ\#305869/2013-2 and PQ\#308649/2011-7).

\section{REFERENCES}

ABESSA, D.M.S. 2002. Avaliação da qualidade de sedimentos do Sistema Estuarino de Santos. DoctorateThesys. University of São Paulo.

ABESSA,D.M.S.,SOUSA,E.C.P.M.,RACHID,B.R.F.,MASTROTI, R.R. 1998.Use of the burrowing amphipod Tiburonellaviscana as tool in marine sediments contaminantionassessment. Braz. Arch. Biol. Technol. 41(2):225-230.

ABESSA, D.M.S. \&SOUSA, E.C.P.M. 2003.Sensitivity of the amphipod Tiburonellaviscana to $\mathrm{K}_{2} \mathrm{Cr}_{2} \mathrm{O}_{7}$. Braz Arch. Biol. Technol.46(1):53-55.

ABNT (Associação Brasileira de Normas Técnicas). 2007. Ecotoxicologia Aquática-Toxicidade em sedimento-Método de ensaio com Hyalellaspp (Amphipoda). ABNT NBR 15470:2007.

ABNT (Associação Brasileira de Normas Técnicas). 2008. Qualidade da água - Determinação da toxicidade aguda de sedimentos marinhos ou estuarino com anfípodes. ABNT NBR 15638:2008.

ADAMS, W.J., KIMERLE, R.A., MOSHER, R.G. 1985.Aquatic safety assessment of chemicals sobbed to sediments. Aquatic Toxicologyand Hazard Assessment: 7th Symposium STP 854. ASTM. 429-453.

ANDERSON, B.S., LOWE, S., PHILLIPS, B.M., HUNT, J.W., VORHEES, J.2008.Relative sensitivities of toxicity test protocols with the amphipods Eohaustoriusestuarius and Ampeliscaabdita. Ecotox. Environ. Safe. 69: 24-31.

APHA, AWWA, WPCP. 1998. Standard Methods for the examination of water and wastewater 19th edition. American PublicHealth Association/American Water Works Association/ Water PollutionControl Federation.

ARAÚJO, R.P.A., BOTTA-PASCHOAL, C.M.R., SILVERIO, P.F., ALMEIDA, F.V., RODRIGUES, P.F., UMBUZEIRO, G.A., JARDIM, W.F., MOZETO,A.A. 2006. Application of toxicity identification evaluation to sediment in a highly contaminated water reservoir in a southeastern.Braz. Arch. Biol. Technol.25: 581-588.

ASTM. 2014. Standard Test Method forMeasuring the Toxicity of Sediment-Associated Contaminants with Estuarineand Marine Invertebrates. E1367 - 03.

BARNARD, J.L. \& KARAMAN, G.S. 1991. The families and genera of marine amphipoda (except marine gammaroids). Record of the Australian Museum. Supplement 13, part 1-2: 1-866.

BASALLOTE, M.D., DELVALLS, T.Á.,, RIBA, I. 2014.Studying the effect of $\mathrm{CO}_{2}$ Induced acidification on sediment toxicity using acute amphipod toxicity test. Environ. Sci. Technol. 48: 88648872. https://doi.org/10.1021/es5015373

BAT, L., RAFFAELLI, D. 1998.Sediment toxicity testing: a bioassay approach using the amphipod Corophiumvolutator and thepolychaeteArenicola marina. J. Exp. Marine Biol.Ecol. 226, 217-239.

BERTOLETTI, E. 2011.A escolha do anfípodo bentônico para ensaios eco toxicológicos com sedimentos marinhos. J. Braz. Soc.Ecotoxicol. 6: 1-7.

BOHRER, M.B.C. 1995.Biomonitoramento das Lagoas de Tratamento terciário dos efluentes líquidos industriais (sitel) do pólo petroquímico do sul, triunfo, RS, através da comunidade zooplantônica. DoctorateThesys.Universidade Federal deSão Carlos.

CARRETERO, J.A., RUSO, Y.D., CASALDUERO, F.G., LIZASO, J.L.S. 2012.Sensitivity of amphipods to sewage pollution. Estuar Coast.Shelf Sci. 96: 129-138.

CESAR, A., MARÍN-GUIRAO, L., VITA, R., MARÍN, A. 2002. Sensibilidad de anfípodos y erizos del Mar Mediterráneo a substancias tóxicas de referencia. Ciencias Marina. 28(4): 407417

CESAR, A., MARÍN, A., MARÍN-GUIRAO, L., VITA, R. 2004. Amphipod and sea urchin tests to assess the toxicity of Mediterranean sediments: the case of Portmán Bay. Ciencias Marina. 68: 205-213.

ENVIRONMENT CANADA. 1992. Biological test method: acute test for sediment toxicity using marine or estuarine amphipods. Report EPS 1/RM/26. Environment Canada, Ottawa.

ENVIRONMENT CANADA. 1995. Guidance document onmeasurement of toxicity test precision using control sediment spiked with a reference toxicant. Report EPS 1/RM/5. Environmental Technology Centre, Ottawa, ON.

FISH, J.D.\& PREECE, G.S.1970. The annual reproductive patterns of Barhyporeiapilosaand Bathyporeiapelagica(Crustacea: Amphipoda). J. Mar.Biol. Ass.UK, 50: 475-488.

GOULDING, T., DE ORTE, M.R., SZALAJ, D., BASALLOTE, M.D., DELVALLS, T.A., CESAR, A. 2017. Assessment of the environmental impacts of Ocean acidification $(\mathrm{OA})$ and Carbon Capture and Storage (CCS) leaks using the amphipod Hayleyoungi. Ecotoxicology. https://doi.org/10.1007/s10646017-1783-6

HAMILTON, M.A., RUSSO, R.C., THURSTON, R.V. 1977. Trimmed Spearman-Karber method for estimating median lethal concentrations in toxicological bioassays. Environ. Sci.Technol. 11: 714-719; correction 12: 417, 1978.

KING, C.K., GALE, S.A., HYNE, R.V., STAUBER, J.L., SIMPSON, S.L., HICKEY, C.W. 2006.Sensitivities of Australian and New 
Zealand amphipods to copper and zinc in waters and metalspiked sediments. Chemosphere. 63, 1466-1476.

KINNE,O. 1961.Sex determination of the flea crab Gammarus duebeniLillj. (Amphipods) is temperature-related - a response. .Crustaceana. 3: 56-69.

KOHN, N.P., WORD, J.Q., NIYOGI, D.K. 1994. Acute toxicity of ammonia to four species of marine amphipod. Mar.Environ. Res. 38: $1-15$.

MELO, S.L.R. 1993. Testes de toxicidade com sedimentos marinhos: adequação de metodologia para o anfípodo escavador Tiburonellaviscana. Dissertation.Universidade de São Paulo.

MELO, S.L.R., ABESSA,D.M.S. 2002. Testes de toxicidade com sedimentos utilizando anfípodos. In: Nascimento IA, Sousa ECPM, Nipper M (ed) Métodos em Ecotoxicologia Marinha Aplicações no Brasil, edn. Artes Gráficas e Industrias Ltda, 163 -178 (in Portuguese).

MELO, S.L.R.\& NIPPER, M. 2007.Sediment toxicity tests using the burrowing amphipod Tiburonellaviscana (Amphipoda: Platyischnopidae). Ecotox.Environ. Safe.66: 412 - 420.

MOLISANI, M.M., COSTA, R.N., CUNHA, P., REZENDE, C.E., FERREIRA, M.I.P., ESTEVES, F.A. 2013.Acute toxicity with de amphipod, Grandidierellabonnieroides after exposure to sediments from an urban estuary (Macaé River Estuary, RJ, Brazil). Bull.Environ.Contam.Toxicol. 90:79- 84.https://doi. org/10.1007/s00128-012-0871-9

NIPPER, M.G., GREENSTEIN, D.J., BAY, S.M.1989. Short and long-term sediment toxicity test methods with the amphipod Grandidierella japonica. Environ.Toxicol.Chem.8: 1191-1200.

OTHMAN, M.S., PASCOE, D. 2007. Bioconcentration and depuration of copper, cadmium, and zinc mixtures by the freshwater amphipod Hyalellaazteca. Ecotox. Environ. Safe. 66, 29-35.

PASSARELLI, M.C., CESAR, A., ABESSA, D.M.S. 2016. Using the amphipod Hyalenigra to assess the quality of marine sediments. Liminol. Ocean.2(1): 007-0055.

PETROVIC, M. \&BARCELÓ,D. 2004. Seeking harmonisation in assessing sediments and dredged materials. Meeting report. Trend.Analyt. Chem. 23. 8: 10-12.

PICONE, M., BERGAMIN, M., ALESSANDRA, O.N., NOVENTA, S., DELANEY, E., BARBANTI, A., GHIRARDINI, A.V. 2008.
Evaluation of Corophiumorientale as bioindicator for Venice Lagoon: sensitivity assessment and toxicity-score proposal. Ecotox. Environ. Safe. 70: $170-184$.

PODLESINSKA, W. and DABROWSKA, H. 2019. Amphipods in estuarine and marine quality assessment - a review. Oceanologia. 61(2), 179-196https://doi.org/10.1016/j.oceano.2018.09.002

PRATO, E., BIANDOLINO, F. 2006. Monocorophiuminsidiosum(C rustacea, Amphipoda) as a candidate species in sediment toxicity testing. Bull.Environ.Contam.Toxicol. 77, 18.

PRATO, E., DI LEO, A., BIANDOLINO, F., CARDELLICCHIO, N. 2006.Sediment toxicity tests using two species of marine amphipods: Gammarus aequicauda and Corophiuminsidiosum. Bull.Environ.Contam.Toxicol. 76: 629-639.

RAINBOW, P.S., LUOMA, S.N. 2001. Metal toxicity, uptake an bioaccumulation in aquatic invertebrates-Modelling zinc in crustaceans. Aquat.Toxicol. 105, 455- 465.

RÉ, A., FREITAS, R., SAMPAIO, A.M.R., QUINTINO, V. 2009. Estuarine sediment acute toxicity testing with the European amphipod Corophiummultisetosum Stock, 1952. Chemosphere. 76: 1323 - 1333.

SEREJO, C.S. 2001. A new species of amphipod from the Brazilian coast, with redescription of HyalespinidactylaChevreux, 1925 (Crustacea, Amphipoda, Hyalidae). Zoosystema. 23 (3): 479492.

SWARTZ, R.C., DEBEN, W.A., JONES, J.K.P., LAMBERSON, J.O., COLE,F.A. 1985.Phoxocephalid amphipod bioassay for marine sediment toxicity. In: Aquatic Toxicology and Hazard Assessment: Seventh Symposium. STP 854 (ed) Cardwell RD, Purdy R \&BahnerRC.ASTM. 208-307.

USEPA (Environmental Protection Agency). 1994. Methods for assessing the toxicity of sediment - associated contaminants with estuarine and marine amphipods. Office of Water, Washington, DC.EPA/600/R-94/025.

USEPA (Environmental Protection Agency). 1996.Guidelines for Reproductive Toxicity Risk Assessment. Published on October 31, 1996, Federal Register 61(212):56274-56322

USEPA (Environmental Protection Agency). 2002. Methods for Measuring the Acute Toxicity of Effluents and Receiving Waters to Freshwater and Marine Organisms. Fifth Edition. 